\title{
GREEN PROCESSING AND SYNTHESIS
}

\section{EDITOR-IN-CHIEF}

Volker Hessel

School of Chemical Engineering

The University of Adelaide, Australia

\section{EDITORS}

\section{Galip Akay}

Formerly School of Chemical Engineering and Advanced Materials

Newcastle University, UK

\section{Isabel Arends}

Biocatalysis and Organic Chemistry, Department of Biotechnology

Delft University of Technology, The Netherlands

Michael C. Cann

Environmental Science at Chemistry Department

University of Scranton, USA

\section{Yi Cheng}

Beijing Key Laboratory of Green Reaction Engineering and Technology

Tsinghua University Beijing, China

\section{Giancarlo Cravotto}

Organic Chemistry

University of Torino, Italy

Heidrun Gruber-Wölfler

Institute of Process and Particle Engineering

Graz University of Technology, Austria

\section{Dana Kralisch}

Institute for Technical Chemistry and Environmental Chemistry

Friedrich Schiller University Jena, Germany

Krishna D. P. Nigam

Department of Chemical Engineering

Institute of Technology Delhi, India

Basu Saha

Chemical and Petroleum Engineering, School of Engineering

London South Bank University, UK

\section{Christophe A. Serra}

European Engineering School of Chemistry, Polymers and Materials Science

University of Strasbourg, France

\section{Wei Zhang}

Boston Center for Green Chemistry

University of Massachusetts Boston, USA

\section{DE GRUYTER}


ABSTRACTED/INDEXED IN Baidu Scholar · Chemical Abstracts Service (CAS): CAplus; SciFinder · CNKI Scholar (China National Knowledge Infrastructure) · CNPIEC · Dimensions · EBSCO (relevant databases) · EBSCO Discovery Service · Engineering Village · Genamics JournalSeek · GeoArchive · Google Scholar · Inspec · Japan Science and Technology Agency (JST) · J-Gate · Journal Citation Reports/Science Edition · JournalGuide · JournalTOCs $\cdot$ KESLI-NDSL (Korean National Discovery for Science Leaders) · Microsoft Academic $\cdot$ Naviga (Softweco) $\cdot$ Norwegian Register for Scientific Journals, Series and Publishers · Paperbase · Pirabase · Polymer Library · Primo Central (ExLibris) · ProQuest (relevant databases) · Publons · ReadCube · Reaxys · SCImago (SJR) · SCOPUS · Sherpa/RoMEO · Summon (Serials Solutions/ProQuest) · TDNet · TEMA Technik und Management · Ulrich's Periodicals Directory/ulrichsweb · WanFang Data - Web of Science: Current Contents/Physical, Chemical and Earth Sciences; Science Citation Index Expanded · WorldCat (OCLC)

The publisher, together with the authors and editors, has taken great pains to ensure that all information presented in this work (programs, applications, amounts, dosages, etc.) reflects the standard of knowledge at the time of publication. Despite careful manuscript preparation and proof correction, errors can nevertheless occur. Authors, editors and publisher disclaim all responsibility for any errors or omissions of liability for the results obtained from use of the information, or parts thereof, contained in this work.

The citation of registered names, trade names, trademarks, etc. in this work does not imply, even in the absence of a specific statement, that such names are exempt from laws and regulations protecting trademarks etc. and therefore free for general use.

ISSN 2191-9542 · e-ISSN 2191-9550

All information regarding notes for contributors, subscriptions, Open access, back volumes and orders is available online at www.degruyter.com/gps

RESPONSIBLE EDITOR Prof. Volker Hessel, School of Chemical Engineering, The University of Adelaide, North Terrace Campus, Engineering North Building, N210, Adelaide, South Australia 5005, Australia, Tel.: +61-8-8313 9245, Email: volker.hessel@ adelaide.edu.au

ASSISTANT MANAGING EDITOR Jannelies Smit, Department of Chemical Engineering and Chemistry, Eindhoven University of Technology, Het Kranenveld, Bldg. 14 (Helix), STW 1.50, 5612 AZ Eindhoven, The Netherlands, Tel.: +31-40-247 5280, Email: ST-GPS@ tue.nl

JOURNAL MANAGER Dr. Gunda Stöber, De Gruyter, Genthiner Straße 13, 10785 Berlin, Germany, Tel.: +49 (0)30 260 05-279, Fax: +49 (0)30 260 05-298, Email: gps.editorial@ degruyter.com

RESPONSIBLE FOR ADVERTISEMENTS Claudia Neumann, De Gruyter, Genthiner Straße 13, 10785 Berlin, Germany. Tel.: +49 (0)30.260 05-226, Fax: +49 (0)30.260 05-264, Email: anzeigen@ degruyter.com

(C) 2018 Walter de Gruyter GmbH, Berlin/Boston

TYPESETTING Compuscript Ltd., Shannon, Ireland

PRINTING Franz X. Stückle Druck und Verlag e.K., Ettenheim

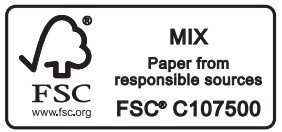




\section{Contents}

\section{Original articles}

Achilleas Constantinou, Simon Barrass

and Asterios Gavriilidis

$\mathrm{CO}_{2}$ absorption in flat membrane microstructured contactors of different wettability using aqueous solution of $\mathrm{NaOH}-471$

Vivek Sharma, Priyanka Srivastava, Santosh Kumar Bhardwaj and D.D. Agarwal lodination of industrially important aromatic compounds using $\mathrm{N}$-iodosuccinimide by grinding method -477

Bashir Ahmad Dar, Zahed Zaheer, Samreen Fatema and Mazahar Farooqui $\mathrm{Cu}(\mathrm{OH})_{\mathrm{x}}$-clay catalyst promoted synthesis of 4,5-dihydro1,2,4-oxadiazole at room temperature - 487

Sarah Patumona Manalu, Thillai Sivakumar Natarajan, Manuel De Guzman, Ya-Fen Wang, Tien-Chin Chang, Feng-Chi Yen and Sheng-Jie You

Synthesis of ternary g- $\mathrm{C}_{3} \mathrm{~N}_{4} / \mathrm{Bi}_{2} \mathrm{MoO}_{6} / \mathrm{TiO}_{2}$ nanotube composite photocatalysts for the decolorization of dyes under visible light and direct sunlight irradiation -493

\section{Wu Zhang}

Preparation of the anatase phase $\mathrm{TiO}_{2}$ nanocrystallites using subcritical water as the solvent and evaluation of their photocatalytic properties under visible light irradiation -506

Rania Zaky and Ahmed Fekri

Solvent-free mechanochemical synthesis of $\mathrm{Zn}(\mathrm{II}), \mathrm{Cd}(\mathrm{II})$, and $\mathrm{Cu}$ (II) complexes with 1-(4-methoxyphenyl)-4-(2(1-(pyridin-2-yl)ethylidene)hydrazinyl)-1H-pyrrole-3carbonitrile -515
Mauricio M. Victor, Jorge M. David, Maria C.K. Sakukuma, Elivana L. França and Anna V.J. Nunes

A simple and efficient process for the extraction of naringin from grapefruit peel waste -524

Milad Torabfam and Hoda Jafarizadeh-Malmiri Microwave-enhanced silver nanoparticle synthesis using chitosan biopolymer: optimization of the process conditions and evaluation of their characteristics $-\mathbf{5 3 0}$

Yuqian Chen, Junwen Zhou, Libo Zhang, Jinhui Peng, Shiwei Li, Shaohua Yin, Kun Yang and Yaping Lin Microwave-assisted and regular leaching of germanium from the germanium-rich lignite ash -538

Liqun Xie, Tingan Zhang, Guozhi Lv, Jinlin Yang and Yanxiu Wang

The effect of $\mathrm{NaOH}$ on the direct calcificationcarbonation method for processing of Bayer process red mud -546

Jin Li and Hongzhou Ma

Zinc and lead recovery from jarosite residues produced in zinc hydrometallurgy by vacuum reduction and distillation -552

\section{Book review}

Mariette M. Pereira and Mário J.F. Calvette (Eds.)

Sustainable synthesis of pharmaceuticals: using transition-metal complexes as catalysts (Lukas Schober) - $\mathbf{5 5 8}$ 